Mediterranean Journal of Humanities mjh.akdeniz.edu.tr $\mathrm{I} / 2,2011,105-115$

\title{
Western Quarantine - Excluding the "Other"*
}

\author{
Batı Karantinası - “Öteki”ni Dışlamak
}

T. M. P. DUGGAN**

\begin{abstract}
This paper employs examples of $19^{\text {th }}$ century travel literature and other sources to explore the nature of the system of western general quarantine which began in the $15^{\text {th }}$ century and continued into the $20^{\text {th }}$ century. It records $19^{\text {th }}$ century western travellers often deliberate disregard for non-western quarantine measures in the Ottoman Sultanate, the employment of quarantine-style settlements in western colonies forming an integral part of western apartheid and racist systems and, the use of disease, quarantine and the absence of quarantine measures, as weapons employed by the western powers against the "other", being the rest of the worlds' populations, as a part of the process and practice of western colonisation and imperialism.
\end{abstract}

Keywords: Quarantine, Exclusion, Satalya-Antalya, plague, othering, racial segregation

Özet: Bu makale 19. yüzyıl seyahat edebiyatından ve diğer örneklerden yararlanarak 15. yüzyılda başlayan ve 20. yüzyıla kadar devam eden batıya özgü karantina kavramını irdelemektedir. Çalışma, Osmanlı Sultanlığı'na özgü karantina deneyimini dışlayan 19. yüzyılda batılı seyyahlarının kaleminden karantinaya alınmış bölge ve insanları, ırkçı ve ayrımcı sistemin parçaları olan kolonileri, salgın hastalıkları, ötekine karşı kullanılan silahları ele almakta ve bütün bunların batılı koloniciliğin ve emperyalizmin dünya nüfusları üzerindeki etkisini ortaya koymaktadır.

Anahtar Sözcükler: Karantina, dışlama, Satalya-Antalya, veba, ötekileme, ırksal ayrım

The western general quarantine was employed to defend the west itself, but the colonies and subject populations of the $19^{\text {th }}$ century western imperial-colonial powers throughout the world were, in many cases not protected by any imperial-colonial quarantine system. This was because other interests took precedence over the health of the subject populations, such as the financial cost of these measures, their impact upon free trade, upon shipping profits and upon the circulation of labour and of native and colonial garrison troops. The exclusionary nature of western quarantine policies is best observed in the total lack of quarantine for native subjects of the British Empire, spread over a quarter of the world's surface, except if the native wished to visit Britain or other western countries. One rule for the west, the greatest vector of epidemic disease in the world over the past 500 years, as McNeill $(1976,199-234)$ records, quite another rule applied to the non-western "other" by the western colonial powers.

There was no quarantine for European explorers, troops, colonial settlers, traders or $19^{\text {th }}$ century tourists (In respect to tourists, Thomas Cook organised the first of his "Eastern Tours", to Egypt and Palestine in 1869, Sattin, 1988, 138. Although there were organised tours to

\footnotetext{
* This paper was presented at the $I V^{\text {th }}$ International Conference of Literatures in English: The Endangered Planet in Literature, held at Doğuş University, Istanbul, Nov. 16-18, 2005, however the proceedings of this international conference remain todate unpublished, www3.dogus.edu.tr/ConferenceofLiteratures/index $2 . \mathrm{htm}$

${ }^{* *}$ Sanat Tarihçi, Akdeniz Üniversitesi, Edebiyat Fakültesi, Antalya, tmpduggan@yahoo.com
} 
Palestine in the 1850's, the bulk of all tourists to Palestine between 1868 and 1882, 4.200, were brought by Thomas Cook, see Shepherd, 1987, 170-192, and, as a consequence of the 1869 tour, William Howard Russell of the London Times, newspaper wrote, "Cooks tourists have arrived... the tourists are all over the place". On the absence of quarantine for those outward bound from Europe to Malta and the Levant in 1853, see for example B. Dorr's $(1856,15)$ typical remarks, departing from European ports to the rest of the world with cargoes including malaria, smallpox, tuberculosis and cholera, while the populations of colonised and subject countries were largely unprotected by any quarantine measures at their colonial administered ports, in India, Ceylon or Java for example, and the western imperialist's distribution of diseases such as cholera, spread by British recruited Bengali sepoy troops to populations throughout the world from its endemic reservoir in British ruled Bengal in the first decades of the $19^{\text {th }}$ century (For cholera pre-1816, W. H. McNeill $(1976,262)$ writes: "One may safely assume that well defined customs pretty well confined the dissemination of the infection to the range of the Hindu pilgrimage), in contrast to the traditional practice of a local quarantine (The traditional response of native peoples through custom and taboo to epidemic disease such as plague or cholera contained and limited the threat, but, with the arrival of outsiders ignorant of local tradition, such as the British East India Company army recruiters in Bengal in 1816-17, or immigrant Han Chinese marmot trappers in Mongolia in the first decades of the $20^{\text {th }}$ century, cholera from Bengal and plague from Mongolia were able to leave their endemic locations and rapidly spread around the world killing millions of people, McNeill, 1976, 194, 155-156, 160-161), reveals a callous disregard for the life of non-western populations that is quite remarkable when juxtaposed with the west's avowed $19^{\text {th }}$ century "civilising mission" to the rest of the world (In respect to the west's "civilising mission" around the world, see for example Kiernan's penetrating remarks, Kiernan, 1998, 146, 158-159, 163-164 and 180-181).

"The Hungarian on the north, and the Turk and the Servian (Serbian) on the southern side of the Save, are as much asunder as though there were fifty broad provinces that lay between them, of the men that bustled around me in the streets of Semlin (Zemun-Serbia), there was not, perhaps, one who had ever gone down to look upon the stranger race dwelling under the walls of the opposite castle. It is the plague, and the dread of plague, that divides one people from another. All coming and going stands forbidden by the terrors of the yellow flag. If you dare to break the laws of quarantine, you will be tried with military haste: the court will scream out its sentence to you from a tribunal some fifty yards off: the priest, instead of gently whispering at you the sweet hopes of religion, will console you at duelling distance, and after that you will find yourself carefully shot and carelessly buried in the ground of the Lazaretto" (Kinglake, $1844,7)$..."He (the officer) then advanced, and asked once more if we had done with the civilised world, held forth his hand - I met it with mine, and there was an end to Christendom for many a day to come" (Kinglake, 1844, 8). Such was the quarantine barrier erected between western Europe and the rest of the world in 1834 as described by Alexander W. Kinglake in "Eothen", who then, in the course of his travels in the Levant deliberately proceeded to wander the streets of plague ravaged Cairo while 80.000 natives, one in three of Cairo's population died of plague (Kinglake, 1844, 160-181; Lane, 1860, 3, fn. 1; Sattin, 1988, 73. 200.000 people died of plague in Egypt during this 1834 outbreak, which then spread to Cyprus where one third of the population died of plague, and then it was conveyed to the huge Ottoman province of Konya, which included all of modern Konya, Karaman and Antalya provinces, where it raged with extreme ferocity from 1835-40 causing a similar loss of life, see, Duggan, 2004, 149; 2005, 368-370) and he then deliberately broke the Ottoman (non-western) quarantine regulations in force at the Ottoman port of Satalieh (Antalya) to protect the population of Antalya from plague which could be brought into the port by shipping from plague infected Egypt, Cyprus and Syria, on his return journey towards "the civilised world"-Europe, giving a display of western Anglo- 
Russian arrogance and power over Ottoman law and a blatant disregard for the health of the Ottoman population inhabiting the port of Antalya (Kinglake, 1844, 134-137).

Unlike many parts of the world where a local quarantine was practiced at the outbreak of any epidemic, a practice employed in the Islamic world by Muslims from the VII ${ }^{\text {th }}$ century onwards (Duggan, 2005, 371-373), Western Christian European states imposed a general quarantine upon all coming from the East regardless of the presence or absence of plague or other contagious disease, defining the "other" automatically as at least potentially diseased, yet, there was no quarantine on people outward bound from the west often carrying a variety of diseases. This western general quarantine system began after the plague pandemic that reached Europe in 1348, was institutionalised at the maritime state of Ragusa in 1465, in Venice in 1485 , at Rhodes in 1503 and Malta in 1522 , and which, from the $16^{\text {th }}$ century onwards, became common at Christian ports around the Mediterranean (McNeill, 1976, 170, fig. 36, 171; Duggan, 2005, 353 regarding Rhodes). By 1739 the land border between Austria-Hungary and the territory of the Ottoman Sultanate was patrolled by 4.000 troops with orders to shoot on sight anybody attempting to unofficially cross the border into Europe, while anyone legally crossing the border had to undergo 48 days confinement (quarantine) and anyone who developed or was thought to have plague symptoms during this period of confinement was shot on the spot and, all goods crossing the border into Europe were to be fumigated and stored (Naphy, \& Spicer, 2004, 171-172). Yet the incubation period for the plague is between two and eight days and this was known in the $14^{\text {th }}$ century (Both the symptoms and the incubation period for bubonic plague were known in the $14^{\text {th }}$ century see, Zeigler, 1973, 27-28), thus the 48 day quarantine imposed when crossing the border into Europe entailed 40 days-worth of nonmedical punishment-imprisonment and seems to have been designed to reduce imports from and contact with the "other" upon European soil. This system of general quarantine had by the $19^{\text {th }}$ century, evolved into a barrier to contact with the "other", having little to do with scientific knowledge of the spread, the transmission of disease, and rather more to do with fear of the "other", of contact with the alien, the "uncivilised" - meaning all non-western Europeans, combined with a deep seated fear of the adjacent Islamic world.

Quarantine was not only the price the adventurous European paid for having contact with the "other", but was a process that defined the "other", the non-European, as diseased and unclean, as the "uncivilised" - one had to pass through a decontamination station, a Lazaretto, before one could be admitted or re-admitted into European society. A point that Sir Charles Fellows drew attention to in his diary entries written in the Syra (Siros) quarantine station in the Cyclades: "Disinfection was insisted upon by all European nations for people, merchandise and letters coming from the Levant, as a necessary precaution to stop the spread of plague and other contagious epidemics in the East", and, "Quarantine and the existence of a regular post mark the verge of our European world" (Slatter, 1994, 193-195). This passage was in fact written more than 30 years after the Ottoman Sultanate had in fact instituted its own quarantine system.

The idea of a non-Christian non-Western power, such as the Ottoman Sultanate, or even the emerging Greek state, protecting its own population from epidemic disease through the institution of quarantine was often treated as a joke by $19^{\text {th }}$ century western European and American travellers and was mocked and flouted in word and practice, in part as an expression of power by the dominant $19^{\text {th }}$ century Western powers, by Kinglake and a nameless Russian General, by Sir Thomas Maitland, by the American William Fogg and by others (See also for example, Hamilton, 1847, vol. II, 51, "We had some difficulty in getting ashore (at Rhodes harbour) in the dark, having landed on the quarantine ground, but finding ourselves locked in, we discovered our mistake before we were perceived and got safely off"! Fortunately it appears 
without also carrying off any communicable diseases from their inadvertent disembarkation in the Rhodes Lazaretto. For diseases in and outbreaks of disease from the Ottoman LazarettoQuarantine station in Beirut in the $19^{\text {th }}$ century see, Fawaz, 1983, 9, 33-34, 43).

General Sir George Whitmore travelled to Zante (Corfu) in 1815 with the British High Commissioner to the Seven Islands, Sir Thomas Maitland and Whitmore records, "We were still in quarantine with the continental ports and plague had broken out in Corfu, but these points were disregarded. A house at Zante at a distance of a mile or two from the town was barricaded and the farce of keeping quarantine for the first week tolerably well maintained. He, Sir Thomas Maitland, however, soon put us into practique and accepted an invitation from Count Comuto to a formal dinner" (Ed. Johnson, 1987, 47; Whitmore had fought the plague outbreak in Malta from April to October 1813 and, through segregation and cordons (a local quarantine) and a considerable amount of good fortune, in part due to the lack of density of population on the island of Corfu at this time, he also restricted the outbreak of plague there in 1815). A. W. Kinglake (1844, 134-137) records in Eothen his deliberate breaking of the Ottoman quarantine imposed on all vessels coming from plague struck Syria in 1835 in the following words: "The town of Satalieh (Antalya) is the chief place of the Pashalik in which it is situate, and its citadel is the residence of the Pasha. We had scarcely dropped our anchor, when a boat from the shore came alongside with officers on board. These men announced a strict quarantine of three weeks on all vessels coming from Syria, and they directed accordingly that no one from the vessel should disembark. In reply, we sent a message to the Pasha, setting forth the rank and titles of the General (a Russian General), and required permission to go ashore. After a while the boat came alongside again, and the officers, declaring the orders received from Constantinople were imperative and unexceptional, formally enjoined us in the name of the Pasha to abstain from any attempt to land...I proposed that we (a party including the General) should set the Pasha at defiance... We determined to land... We ordered the boat to be got in readiness, and the officers on shore, seeing these preparations, gathered together a number of guards; these they assembled upon the sands; we saw great excitement prevailed, and that messengers were continually going to and fro between the shore and the citadel...My instructions to the Captain (of the ship) were attended to with the most perfect accuracy, for scarcely had my foot indented the sand when the four six-pounders of the brigantine quite gravely rolled out their brute thunder. Precisely as I had expected, the guards, and all the people who had gathered about them, gave way under the shock produced by the mere sound of guns, and we were allowed to disembark without the least molestation. Likewise W. W. Smyth in his book, A year with the Turks or sketches of travel in European and Asiatic Dominions of the Sultan, of 1854 (Redfield, New York), exhibits this same attitude towards Ottoman quarantine when he writes of his "Great indignation at the idea of detention" for quarantine, and his evasion of it on p. 126: We were not very far from the town of (Sivas) when a man issuing from a mud cabin (an adobe home), informed us that, if we came from Mossul (Mosul), we must perform quarantine; whilst at the same time the rustics who had kept company with us, and flock of sheep which they drove were allowed to pass. We of course put on an air of great indignation at the idea of detention, and ordered him to take our passports direct to the Pasha, whilst we would await an answer. He had, however, been gone but for a few minites when he returned and said that though he had not been to the Pasha, his superior officer had instructed him to let us pass without delay; nor did he forget to accompany the message with a humble request for buckshish. Such was the quarantine cordon, kept up, no doubt, chiefly for the extortion of fees". Additions in brackets to the text are mine). The American William Perry Fogg relates his deliberate breaking of the Ottoman quarantine regulations then in force on the Euphrates River by Ottoman Basra in 1874: "But now a new difficulty arose. Our ship had not received practique, and we had no right to land. If the health officers should see us we would be arrested for violating quarantine regulations. 
There is no other country in the world where quarantine regulations are so stringent as in Turkey. In this matter even money is useless. This country (the Ottoman Sultanate) has so often suffered from the frightening ravages of plague and cholera that a most vigorous system is enforced with all ships coming into Turkish ports... We replaced our Indian pith hats, which are only worn by Europeans, with the red Turkish fez, and directed our boatman to keep close to the opposite shore. We took down our sun umbrellas and put out of sight everything that would mark us as strangers. As we passed the guard ship, the officer on deck directed his glass towards our boat, but seeing nothing suspicious allowed us to pass". (Fogg, 1875, 185. British indifference to and non-cooperation with Ottoman sanitation and quarantine regulations is recorded during the outbreak of cholera at Basra in 1904, Ortayl1, 2004,134-135, to be also seen as the expression of the arrogance of Western Imperialists).

Cyrus Hamlin $(1878,303)$ records that the Ottoman quarantine measures instituted at Constantinople were successful against the plague from 1837 onwards while Daniel Panzac (1997, 68-70), in his study of plague in Ottoman territory, records that between 1721 and 1796, $66 \%$ of French flagged ships and $23 \%$ of Venetian flagged ships that arrived at the Ottoman port of Smyrna (Izmir) were infected with plague, plague was transported by European flagged shipping into and around the coastline of the Sultanate. The Ottoman quarantine system began at the end of the $18^{\text {th }}$ century in Istanbul and had extended by the 1830's to Cyprus, Antalya, Beirut and other ports (Duggan, 2004, 147; 2005, 367), nearly 70 years before quarantine was instituted on Ceylon by the British to protect their subject Sinhalese native population from imported disease.

The British did not apply quarantine controls to British ruled Ceylon, as it would have restricted the movement of migrant Tamil workers from British ruled Southern India to the British owned coffee and then tea plantations of Ceylon, regardless of the health risk to the population, until after the plague epidemic of 1897, brought to Ceylon from India which destroyed the Tamil force at work in the tea plantations and killed thousands of the native Sinhalese (Moxham, 2003, 176). For this same reason, the lack of any quarantine at British Indian ports, 6 million Indians died in the plague outbreak of 1896 that spread from China to the port of Bombay and from there across the country (Zeigler, 1973, 25; Gimpel, 1979, 189). Likewise in the interests of "free trade" and merchant marine profits the British obstructed the implementation of a quarantine system within the British Empire and refused to implement quarantine measures at the point of departure. Further, and for the same short term pecuniary reasons and interests, they blocked the attempts by other Western powers at successive International sanitary conferences, 1851 and 1859 , to enforce quarantine on the haj to Mecca until after the cholera outbreak of 1865 , when one third of the pilgrims from Dutch ruled Java and one third of the pilgrims from British ruled Singapore died in transit to and from Arabia, 15.000 of the 90.000 pilgrims died of cholera in the Hejaz, and subsequently, through contact with pilgrims returning from the haj, 60.000 Egyptians died of cholera and cholera reached Istanbul, Marseilles and in November 1865, New York. Cholera had first reached Mecca in 1831 (Farahani, 1990, 289, fn. 22: Peters, 1994, 302, fn. 32, at the international sanitary conference of February 1866, held in Istanbul, the British delegate objected to a means test for pilgrims making the haj, as the Dutch were already applying to Dutch ruled Moslem pilgrims, objecting simply to support British shipping company profits, Peters, 1994, 304-5). Then after 1865 , quarantine stations were established, not at the point of departure in western Imperial and colonial territory, but within Ottoman territory and administered through European pressure and power, although a major quarantine station had been established at Gaza in Palestine in 1850, amongst other Ottoman health and quarantine facilities for pilgrims (Peters, 1994, 301-315. Cholera first reached Mecca in 1831 which Farahani 1990 misdates to 1817, Farahani, 1990, fn. 
22, 289).

The cordon sanitaire system of a general quarantine was erected by the European states to protect themselves, and to exclude - significantly reduce contact with the "other". It was built at the same time as Europeans were spreading diseases around the world, accidently, as a byproduct of western exploration and contact with the "other" (Neale, 1851, 12-20; McNeill, 199234); and deliberately, as a method of reducing the numbers of the native inhabitants, clearing the ground for white colonial settlement, as in North America from 1633 onwards (Naphy, \& Spicer, 2004, 163, John Winthrop (1588-1649) the Governor of Massachusetts records: "For the natives they are neere all dead of small poxe so the Lord hathe cleared our title to what we possess"; while the Hahuatl people of Central America between 1518 and 1605 were reduced through contact with western imported disease from a population of 25.5 million people to 1.1 million people, Churchill, 1997, 138-140; Naphy, \& Spicer, 2004, 163, regarding the natives of South America and also the native Pacific islanders, native Australians, Siberians and Hottentots likewise devastated by contact with western imported diseases including smallpox, measles, syphilis etc., McNeill, 1976, 227, fn. 47-50), with the deliberate employment of smallpox against the native inhabitants, on smallpox infected blankets given as gifts to the native American Indian tribes in the $18^{\text {th }}$ century by the British (McNeill, 1976, 251, distributed by order of Lord Jeffrey Amhurst in 1763; Churchill, 1997, 154), and in the $19^{\text {th }}$ century by white North Americans to systematically reduce the numbers of the native American population in 1837, (Churchill, 1997, 155-156. See also, for the subsequent history of the deliberate development and deployment of disease-germ warfare capability by British, USA, German, Russian, Italian and Japanese institutions in the $20^{\text {th }}$ century and for the suspected use of plague and other diseases by American forces during the Korean War, the means were present, their utilisation in this conflict remains disputed, Harris, \& Paxman, 2002, 165-166; 170; see also, Blum, 2003, 104-105), that is genocide.

Cholera spread, initially through troop movements from British East India Company ruled Bengal in 1816, where it had been endemic and confined for centuries by a local quarantine, to Nepal and then Afghanistan, reaching Muscat in 1821 and Ceylon, Indonesia and other parts of South-East Asia, Japan and China in this same year; the Gulf, Iraq, Syria and Anatolia and eastwards to the Caspian Sea by 1823, killing many millions of people, this due to the lack of any quarantine for British Indian troops and the use of British Indian troops to fight colonial wars and so thereby to cheaply and with less adverse publicity expand the British Empire (McNeill, 1976, 262-264; Markham, 1995, 8; Porter, 1997, 402; Kiernan, 1998, 53-56, 61, 6667, 104, 184-186; and Farwell, 1973, for the wide use of British Indian troops in the Empire; Peters 1994, 301-315; Moxham, 2000, 130-131, points out that the cholera deaths in British administered India were increased through the salt tax burden on the native population; Wills, 1996,112 , suggests an average death rate from those infected with cholera in the $19^{\text {th }}$ century of $50 \%$ ). Cholera breached British quarantine in Malta in 1837 where it killed 4.233 of a population of 123.000, and struck this British colony again in: 1850, 1854, 1856, 1865, 1867, 1887 and 1911 due to its nodal importance in British troop and trade movements (Savona, Ventura, 1997, 31. Also due to a late $18^{\text {th }}$ century Act of the English Parliament, all ships proceeding to English ports from Ottoman ports had to undergo quarantine in Malta, as there were no quarantine-Lazaretto facilities available in England and, of course, any possible outbreak of disease would be restricted to this distant Catholic Island's facilities; Attard, 1995, 60. For an account of the British run quarantine station at Malta, Manoel Island, in the $19^{\text {th }}$ century, see Gifford, 1837, 34 ff). Cholera reached across Europe to the Baltic Sea in 18301831, spread from Ireland in 1831 to London in 1832 when it killed 7.000 and reached the Republic of the United States of America the same year and Mexico in 1833. It struck England 
again in 1848 and killed 62.000 people, while between 1847 and 1861 alone 2.589 .843 Russians contracted cholera and more than half a million Russian died from this disease (McNeill, 1976, 263; Porter, 1997, 402-404), these cholera deaths being yet another of the hidden costs of western imperialism.

The blame for disease was regularly given to the native non-European population, labelling the native "other" as dirty and disease riddled, even though, as Hobhouse remarks, "there was evidence that the white man brought it (disease) with him" (Hobhouse, 1999, 11). Ironically, given the British Imperial distribution of cholera, when the Ottoman delegate at the 1894 International Health Conference, entitled, Sanitary Conference on the Mecca Pilgrimage, in Paris, protested at western interference in the internal affairs of a sovereign state (western control that continued from 1892 to 1957 over quarantine at Jidda in Ottoman and then Saudi, Arabia), he was told, "It was a question not of national sovereignty, but of basic human rights" (Peters, 1994, 304, 315).

It is perhaps not surprising that popular western literature becomes, from the late $19^{\text {th }}$ century onwards, rife with stories of germ warfare - biological warfare employed to "defend" the west against the Chinese threat, such as Matthew P. Shiels, The yellow danger, of 1898, where plague is injected by the Englishman Hardy into some Chinese to destroy the entire Chinese population, or Jack London's short story of 1910, entitled, The Unparalled invasion, where an American scientist develops a germ weapon deployed in the 1970's, to destroy within a year the entire Chinese population, a case of popular literature following the historical facts, as germ warfare employing smallpox had been deliberately conducted against native American populations from $18^{\text {th }}$ century onwards and in the $20^{\text {th }}$ century chemical warfare as well (For the state use of native American Indians in the $20^{\text {th }}$ century for the processing by hand of radioactive yellow cake and for other nuclear industry tasks, see Churchill 1997, 304-346, this work being a classic documented account of the western pattern of treatment of the "other", in this case of the native American in his own land, over the course of 500 years).

Western general quarantine was itself a strange and inconsistent institution, waived entirely or reduced in length in some cases for "important" people (See above fn. 18, for Sir Thomas Maitland awarding practique to himself and to the members of his party in 1815), Grand Master Wignacourt reduced George Sandys's quarantine on arriving in Malta from the Levant in June 1611 to a few days, then he was granted practique; likewise for the Earl of Sandwich in 1739, also arriving in Malta from the Levant, whose quarantine was reduced from one month to twenty days and, in 1831, only 6 days quarantine for Sir Walter Scott arriving in Malta from cholera struck Europe (See Bianchi, \& Inglott, 2000, for references in chronological order of their respective visits to Malta and also of Sandys, Sandwich and Scott's reduced terms of quarantine in Malta) and with the length of time spent in quarantine varying from place to place and from year to year in a quite arbitrary fashion (In addition to the periods of quarantine mentioned in this text, 9-14 days quarantine for ships from N. Africa and the East to Malta between 1530 and 1798, Savona, Ventura, 2004, 48; 40 days quarantine for slaves and their captors at Malta, but reduced due to time at sea free of contact with suspect goods or people, Moslem or Christian, Wettinger, 2002, 173, 557-558: 14 days quarantine for Kinglake if he returned to Hapsburg territory in 1834, Kinglake, 1844, 7; 21 days quarantine at Ottoman Adaliya-Antalya in 1835, Kinglake, 1844, 134: 2 days quarantine at Malta after touching Gibraltar in 1836, E. Gifford (1837, 382-283, and 387-388), Short visit to the Ionian Islands, Athens and the Morea, 1837, 34; yet 8 days quarantine at Zante, Corfu in the same year, for a near revolt by western inmates of the quarantine station at Zante; seven days for Fellows at Malta in 1844, Slatter, 1994, 313-314; yet 14 days at Syra (Siros) in 1840, where he notes that if an epidemic broke out during his stay he would have to spend 40 days more in quarantine, 
Slatter, 1994, 193-194. See also Fellows's comments on reducing the time spent in quarantine between the east and Europe, rather than three weeks quarantine at Syra and two weeks quarantine on the border between Greece and Europe, it was quicker to undergo a single quarantine in Malta and then freely enter Europe. He describes quarantine as "one long imprisonment", Fellows, 1852, 486; 14 days in quarantine at Orsova for Lady Emmeline in 1838 at, "one of the shunned barriers between Europe and the habitually plague-stricken Ottoman empire (sic)", Cust, 1928, 17; 4 days quarantine for Abul Hassan Khan in 1809 before entering England, Cloake, 1988, 24; and 3 days quarantine at Southampton in 1844 for Lutfullah after a long sea voyage, Eastwick 1857, 402; and yet, only 48 hours quarantine for Farahani, only extended if someone died, Farahani, 1990, 291, and deaths were often concealed or bribes paid; and five days shipboard quarantine at Batumi in 1886, if no passenger looked unwell to the inspecting doctor and if the Ottoman heath certificate was in order, Farahani 1990, 302. See also, Howard, 1789 passim. For other bribes paid by Europeans to reduce the time spent in nonwestern quarantine, see for example, Lovell, 1995, 141, 149, only 24 hours of quarantine at Ottoman Jaffa "with the aid of a well-placed baksheesh" in 1853, as opposed to up to five days to be spent in the Ottoman quarantine station in Beirut). As Christian Snouck Hurgronje remarked, "The authorities of quarantine (for the Mecca pilgrimage) especially the chief Doctor, take something from the captains of the steamers so they (the doctors) won't cause any trouble if someone dies during the two days stopped at quarantine, they don't renew the period of quarantine (if somebody dies on board) and don't delay the steamer... The whole quarantine system has no other purpose than exploitation" (Hurgronje, Mekka, 1888-1889, 218). Oddly, given the west's apparent concerns over the possible spread of disease by returning Muslim pilgrims, their return journey quarantine lasted only two days in Egyptian ports in the 1880's and was corrupted by the payment of bribes paid by European steamship captains to the British appointed doctors at these quarantine stations, to prevent any delay to the steamships passage elsewhere!

The idea of quarantine, of a cordon sanitaire (A French term that originally denoted a barrier implemented to stop the spread of disease), was also applied in the establishment of the western European cantonments and colonial settlements throughout much of the non-western colonised world, carefully sited away from centres of the "unclean-diseased native population", as R. Lawless describes of French colonisied Morocco: "Where possible, new cities for European settlers were built some distance from the pre-colonial centres, as at Fez and Marrakesh, and separated from them by a cordon sanitaire or green belt of open land. In this way (General) Lyautey hoped to separate as fully as possible the European inhabitants from the Moroccans and, while the segregation was never as complete as he intended, the basic lines of apartheid were remarkably well maintained" (Lawless, 1981, 266). This western quarantine system established the precedent for the apartheid systems of South Africa, Israel and elsewhere in the colonized world and it institutionalized, and thereby justified racist divides, as H. Hobhouse (1999, 11-12) records, "Europeans were advised never to build within a mile of a native village and never to allow native children into their own house".

The difference between a western $19^{\text {th }}$ century quarantine station or Lazaretto, a reservation for the remaining native population within a country settled by westerners as in the USA or Israel, a late $19^{\text {th }}$ or $20^{\text {th }}$ century British, German or American concentration camp or the USA's detention camps for suspects in Cuba, Afghanistan, Iraq, Poland and Bulgaria as elsewhere today, is slight (Note for example in the aftermath of September $11^{\text {th }} 2001$, CNN discussing the housing of Arab Americans in concentration camps, Miles, 2004, 365); the "other" and those that might just possibly have been in contact with the "other", are to be isolated, as they are or could be diseased in fact or potentially, by virtue of being "other", to be deceased or released 
after some indeterminate time as the case may be. An attitude towards the "other" espoused today by influential western propagandists, such as Samuel P. Huntington in his volume, The Clash of Civilisations and the Remaking of World Order (1997, 198-204; 305-308. Note his adverse comments on immigration to the west, particularly by Moslems and Hispanics and of the need for anti-immigration barriers-quarantine, this after centuries of European immigration to the non-western world which he praises. Note also his deceptive remarks in this matter, as the number of immigrants from the west are not given as a percentage of the total population, consequently, the comparison he draws between western immigration to the rest of the world and subsequent non-western immigration to the west is skewed by global population growth in the $20^{\text {th }}-21^{\text {st }}$ centuries and by his hostility to multiculturalism. See also my review of this book published in the Turkish Daily News, "Book review -The clash of civilizations and the remaking of world order-Modern Western States-A civilization?", Book Review, S. Huntingdon, "The Clash of Civilisations", Part I, Turkish Daily News, p. 16, December 25 $5^{\text {th }}, 2001$, and, "Four alternative paradigms to the clash of Civilisations", Book Review, S. Huntingdon, "The Clash of Civilisations", Part II, Turkish Daily News, p. 16, December $26^{\text {th }}, 2001$, www.turkishdailynews.com.tr.archive).

Like the scars left by billions of television and internet images of the events of September $11^{\text {th }} 2001$, like the records of the Black Death pandemic of the $14^{\text {th }}$ century or Daniel Defoe's imagined $18^{\text {th }}$ century account, A Journal of the Plague Year, or "Cholera-The Black One", in the $19^{\text {th }}$ century; it is not the event or the disease itself, but the way it is manipulated in the west that psychologically scars relations with the "other", creating a climate of distrust, of blame and, in many western minds, a hatred of difference and of insecurity, that is then manipulated by "the civilising mission" of the west towards the rest of the world, towards India, South East Asia and Africa in the $19^{\text {th }}$ century, to Afghanistan, Iraq and elsewhere today. The wide-scale manipulation of these events in the public consciousness seems a particular western propensity, with the western led media orchestrated plague panic in 1994 that swept the globe, when all but two international airlines shut down all flights to India because of an unconfirmed outbreak of plague at Breed, and, in panic at dealing with passengers from the subcontinent, "airport workers at Toronto International Airport, Canada, donned masks and gloves" (Wills, 1996, 1414). As W. Naphy, \& A. Spicer write: "Prejudice and attitudes towards the "other" seem to have lain carefully and quietly behind a facade of concerns about health" Naphy \& Spicer, 2004, 183. Panic at an outbreak of plague and the response to the "other" in these circumstances are discussed in, Curson, 1989, 168-170).

An earlier, deliberate plague scare was recorded by Sir P. Sykes in December 1912: "The Russians declared an outbreak of plague along the Afghan border, which gave them an excuse to close the border and set up quarantine posts, disrupting the trade with India. There was no plague; in fact, some peasants had died after eating an infected camel" (Wynn, 2003, 230).

Amongst the tools used to define and exclude the "other", the fear of disease carried by the "other" forms a powerful subtext within the West's armoury of discrimination (The thinking behind the western attitude, conscious and subconscious towards the "other" as outlined in this paper, seems to have its roots in the West's own self-image as the successor to the Greeks, Macedonians and Romans, slave owning imperial powers; of ownership over democracy, the so-called enlightenment and imperialism, over science, technology and global markets, commodity prices and globalisation, the W.T.O., I.M.F. and the internet; of the western enforcement of global order and of the West's "civilising mission" to the rest of the world; that is, of rule or control over the planet and its peoples, as described in the present USA military doctrine (2003) as, "Full Spectrum Dominance", including the deployment of missiles in space, suitcase sized nuclear devices and the use of lasers to destroy earth orbiting satellite 
communications. The fact that western hegemony has been built upon the appropriation of other civilisations discoveries, knowledge and inventions that are then subsumed into the construct called western civilisation without either acknowledgement or royalties over the centuries and into the present day, from paper and printing to potatoes and maize, the concept of zero and the decimal system, vaccination, gunpowder, spectacles and rockets, to the often illegal collection of non-western plant species for gene manipulation, I think makes the point. The non-western "other" being either of temporary use or a hindrance to the exercise of western global hegemony, as is exposed by statements such as: "Your either with us or against us", by US President George Bush in 2001, or the western refusal to accept the "other" as an equal in fact, to be seen not only in the manner of the establishment of so-called "global institutions" after World War Two, the IMF, World Bank and United Nations, and these institutions policies towards the "other"; but also in various western overt and covert campaigns against Islamic states or any other alternative model to "West-Way" is derided in the Western and todays global western media (for the $19^{\text {th }}$ century precedent for this, see, Rabbani, 1994, vii-ix) and, in time, all alternatives to "West-Way" are to be destroyed leaving a neo-colonial wasteland. An intent made clear by Huntington 1997, 215-18, 312, etc., and by other members of the Western establishment today. Contrary to the thesis of Greek tragedy -that the recognition of guilt will lead to change- in my opinion, western attitudes towards the "other" will remain unchanged, regardless of proven western guilt and genocide towards the "other", see for some examples, Lindquist, 1997. Even the admission of guilt by some western leaders, following the mid- $20^{\text {th }}$ century decolonisation by the western colonial powers, with the exception of the colonial settler state of Israel, served only as a foil, to the far cheaper to run western-led neo-colonialism of today).

\section{REFERENCES}

Attard, J. (1995). Britain and Malta. Malta: PEG.

Bianchi, P. \& Inglott, P., S. (2000). Eds. Encounters with Malta. Malta: Mid-Med Bank.

Churchill, W. (1997). A little matter of genocide-Holocaust and denial in the Americas 1492 to the present. USA: City Lights Books San Francisco.

Cloake, M. M. (1988). Mirza Abul Hassan Khan, A Persian at the Court of King George 1809-10. London: David and Charles.

Curson, P. (1989). Paradise delayed-Infectious diseases in the industrialized world. Ed. Clarke, J. J., Curson, P., Kayastha, S. L., \& Nag, P. Population and Disaster, 168-170. Oxford: Basil Blackwell.

Cust, H. (1928). Wanderers: Episodes from the travels of Lady Emmeline Stuart-Wortley and her daughter Victoria, 1849-1855. London: J. Cape.

Dorr, B. (1856). Notes of Travel in Egypt, the Holy Land, Turkey and Greece. Philadelphia: J. B. Lippinoott $\&$ Co.

Duggan, T. M. P. (2004). A short account of recorded calamities (earthquakes and plagues) in Antalya and related areas over the past 2,300 years-an incomplete list, comments and observations. ADALYA VII, 123-170.

Duggan, T. M. P. (2005) Supplementary data to be added to the chronology of plague and earthquakes in Antalya Province and in adjacent and related areas. ADALYA, VIII, 357-398.

Eastwick, E. B. (1857). Autobiography of Lutfullah-A Mohamedan Gentleman. London: Smith and Elder. Farwell, B. (1973). Queen Victorias' Little Wars. London: Allen Lane.

Fawaz, L. T. (1983). Merchants and Migrants in nineteenth century Beirut. Cambridge-Mass: Harvard University Press.

Fellows, C. (1852). Travels and researches in Asia Minor, More particularly in Lycia. London: John Murray.

Fogg, W. P. (1875). Arabistan or the land of Arabian Nights. London: Dustin Gilman Hartford Con.

Gifford, E. (1837). Short visit to the Ionian Islands, Athens and the Morea. London: John Murray. 
Gimpel, J. (1979). The Medieval Machine. New York: Penguin Books.

Hamilton, W. J. (1847). Researches in Asia Minor, Pontus and Armenia, vol. 2. London: John Murray. Hamlin, C. (1878). Among the Turks in the Turkish Empire (sic). New York: Robert Carter and Brothers. Harris, R., \& Paxman, G. (2002). A higher form of killing. London: Random House.

Hobhouse, H. (1999). Seeds of Change; six plants that transformed mankind. London: Macmillan.

Howard, J. (1789). An account of the principal Lazarettos in Europe, London. London: William Eyres.

Huntington, S. (1997). The clash of civilisations and the remaking of World Order. New York: Simon and Schuster.

Hurgronje, C. S. (1931). Mekka in the latter part of the 19th century: daily life, customs and learning of the Moslims of the East-Indian-Archipelago. Trans. J. H. Monahan. Leiden: Brill.

Kinglake, A. W. (1844). Eothen. London: J. Olivier.

Kiernan, V. G. (1998). Colonial Empires and Armies 1815-1960. Montreal: McGill-Queen's University Press.

Lawless, R. I. (1981). Social and Economic change in North African Medinas. Ed. Clarke, J. I., \& Bowen, J. H. Change and development in the Middle East. Essays in honour of W. B. Fisher. London: Methuen.

Lindquist, S. (1997). Exterminate all the Brutes. Trans. J. Tate. London: Granta.

Lovell, M. S. (1995). A Scandalous life-The biography of Jane Digby el Mezrab. London: Richard Cohen Books.

McNeill, W. H. (1976). Plagues and Peoples. New York: Anchor Books.

Markham, A. (1995). A Brief History of Pollution. London: St. Martins.

Miles, H. (2004). Al-Jazeera - how Arab TV News Challenged the World. London: Abacus.

Farahani, Mirza, M. H. (1990). A Shi'ite pilgrimage to Mecca, 1885-6. Trans. with Notes, H. Farmayan, \& E. L. Daniel. London: Saqi Books.

Moxham, R. (2003). Tea, addiction, exploitation and Empire. London: Constable and Robinson.

Moxham, R. (2000). The Great Hedge of India. London: Constable.

Naphy, W. \& Spicer, A. (2004). Plague-Black Death and pestilence in Europe. Tempus Publishing Stroud.

Neale, F. A. (1851). Eight Years in Syria, Palestine and Asia Minor from 1842-1850. vol. I, London: Colburn \& Co.

Ortayl, İ. (2004). Ottoman Studies. İstanbul: Bilgi University.

Panzac, D. (1997). Osmanlı Imparatorluğu'nda Veba (1700-1850). Çev. Serap Yılmaz. İstanbul: Tarih Vakfi Yurt Yayın.

Peters, F. E. (1994). The Hajj-The Muslim Pilgrimage to Mecca and the Holy Places. New York: Princeton.

Porter, R. (1997). The Greatest Benefit to Mankind A medical history of humanity from antiquity to the present. London: Harper Collins.

Rabbani, R. (1994). Imperial Fictions - Europe's Myths of Orient. London: Pandora.

Sattin, A. (1988). Lifting the Veil-British Society in Egypt 1769-1956. London: J. M. Dent \& Sons Ltd.

Savona, Ventura, C. (2004). Knight Hospitaller Medicine in Malta 1530-1798. Malta: PEG.

Savona, Ventura, C. (1997). Outlines of Maltese Medical History. Malta: PEG.

Shepherd, N. (1987). The Zealous Intruders - The western rediscovery of Palestine. London: Collins.

Slatter, E. (1994). Xanthus-Travels of discovery in Turkey. London: Rubicon Press.

Smyth, W. W. (1854). A year with the Turks or sketches of travel in European and Asiatic Dominions of the Sultan. New York: Redfield.

Wettinger, G. (2002). Slavery on the Islands of Malta and Gozo ca. 1000-1812. Malta: PEG.

Wills, C. (1996). Plagues, their origin, history and future. London: Harper Collins.

Whitmore, General, Sir G. (1987). The General-The travel memoires of General Sir George Whitmore. Ed. J. Johnson, Sutton: Gloucester.

Wynn, A. (2003). Persia in the Great Game. London: John Murray.

Zeigler, P. (1973). The Black Death. New York: John Day. 